\title{
Liminality and Event Design: Liminal space design for sport events
}

\author{
Ashley Garlick* \\ London Geller College of Hospitality and Tourism \\ University of West London \\ St Mary's Road \\ London \\ W5 5RF \\ Email: ashley.garlick@uwl.ac.uk
}

\author{
Nazia Ali \\ Institute of Hospitality and Tourism \\ University of East London \\ Email: Naz.ali@uel.ac.uk
}

\section{Cite as:}

Garlick, A. and Ali, N., (2019). Liminality and Event Design: Liminal space design for sport events, in: I. Lamond and J. Moss (eds). Exploring Liminality in Critical Event Studies: Boundaries, Borders, and Contestation, Basingstoke: Palgrave Macmillan.

\section{${ }^{*}$ Corresponding author}




\title{
Liminality and Event Design: Liminal space design for sport events
}

\begin{abstract}
:
It has been argued that ritual has been sacrificed to give way to modern event management techniques that prioritise economic viability and stakeholder satisfaction over the ritual purpose of the event (Brown and James, 2004). In this chapter, the authors reject this argument, and instead propose that ritual is undergoing a new resurgence in terms of its impact on event design for sport events. The work contributes to existing research on the symbolic relationship between ritual and liminality in such liminoid happenings as sport events. The authors interpret the relationship between liminality and related terms associated with rituals: celebration, communitas, anti-structure and symbols. These are further discussed in view of design strategies that promote drama (i.e. dramaturgy), arousal of senses (i.e. atmospherics) and interactivity (i.e. servicescapes). It is asserted that, while ritual and liminality is far from extinct, there is an increasing importance for professional (sport) event organisers to show a greater understanding of how it should inform their creative process. This would enable them to execute high quality events that provide memorable experiences. The chapter demonstrates that liminality can inform event design and is a fundamental concept that must be considered for an event to be successful.
\end{abstract}

Key words: Liminality, Liminoid, Ritual, Event Design, Sport Events. 


\section{Introduction}

Rituals are inherent across a range of event types and can be found in different contexts such as cultural, legal, political, religious and social domains. This counterbalances Brown and James (2004) point that ritual has been sacrificed to make way for modern event management techniques that prioritise economic viability and stakeholder satisfaction over the ritual purpose of the event. In this chapter, we reject this argument, and instead propose that ritual is undergoing a new resurgence in terms of its importance to event design beyond the commercial significance. Finkel (2010) also supports the view that commercialisation has become the dominant, most important facet to event organisers. Moreover, throughout history, sport events appear to have a tradition of ritualism with theological underpinnings of spiritual and religious value. The Olympic Games as a Panhellenic sport event in Ancient Greece is an example of a sacred event infused with celebration, ritual and culture (Maussier, 2017). In the world today, the Olympic Games continue to stage the mediation of liminal ritualistic performances; For instance, Lawson's (2011) work on the Opening Ceremony suggests a dialectical negation of pre-modern religious values with modern secular performances. We further argue that liminality, surfacing from ritualism, in sport event design is important in making an event a commercial success. At the heart of liminality in event design, in this chapter, is Victor Turner's (1969) notion of 'liminoid' attached to the liminal phase originally identified by Arnold van Gennep (1960). Lee, Brown, King and Shipway (2016, p.497) appreciate the role of event design in creating liminality as "event design can be used to enhance the liminality of the setting, to disengage people from their daily life, and to increase the emotional intensity of links with other participants." Turner (1969), seeking to situate liminality in 'modern times', therefore coined the term 'liminoid' as an attempt to capture informal, non-traditional and secular ritualistic behaviours. Liminoid can be applied to designing liminal experiences for sport fans participating (as spectators) in the leisure activity of sport. As Thomassen (2009, p.15) explains “... 'liminoid' moments [are] where creativity and uncertainty unfold in art and leisure activities ... in art and leisure we recreate 'life in the conditional', playful ... break from normality ... a playful as-if experience." The main focus is upon designing liminal spaces for sport events to enhance the fan as spectator experience, pre-event, during the event, and post-event.

In this chapter, we will first explore the nature of liminality with a focus on related theoretical and conceptual constructs, which can be further applied to designing liminoid fan or spectator experiences in sport events. The theoretical inspections begin with van Gennep's (1960) initial proposal of liminality, in particular the liminal phase, which is later advanced by Victor Turner's (1969) conceptualisations of liminality in view of liminoid occurrences. Liminality is subsequently applied to the review of rituals and related concepts - celebration, communitas, anti-structure, and symbols, which are also terms embedded in comprehensions of sports events. The chapter proceeds with a discussion of sport events as a liminal experience(s) and liminoid encounter(s) that is embedded with rituals central to celebration, communitas, performance, and symbols. This liminal space - the sport event - represents a tangible and intangible arena to which people escape to temporarily; however, we propose that sport fans 
continue to exist in a 'liminal bubble' seconds, minutes, hours, days, months and even years after spectating the live sport event. Therefore, from an event management practitioner perspective it is important to design sport events that creatively immerse the fan as spectator in the liminal phase by considering the entirety of the experience. In proposing strategies for designing, creatively, liminality in live sport events the paper draws upon Goffman's (1959) theory on dramaturgy, Kotler's (1973) conceptualisations of atmospherics, and Bitner's (1992) application of servicescapes. Nelson (2009) recognises the interrelationships and interdependencies between dramaturgy, atmospherics and servicescapes in creative event design to make and enhance experience and emotional bonds of attendees. Further, in support of this, Ali, Ferdinand, and Chidzey $(2017$, p.68) state "the design of an event is both an experience-maker and experience-enhancer." We conclude that sport events are highly ritualised happenings that continue to be of significance to people, places and populations, and the role of event managers is to create commercially and socially viable 'fluid' liminal spaces in which participants can exist at multiple experience points. Thus, sport fans as spectators can enter, remain, exit and return to the liminal phase at any point of the event cycle (i.e. pre-event, during event or post-event).

\section{The Nature of Liminality and Sport Events}

Arnold van Gennep (1960) introduced the concept of liminality in the interpretation of rites of passage associated with key ritual processes of passing from one place, status, situation or time to another. Liminality, from the Latin word 'limen' meaning a literal 'threshold', can be considered as temporal and transitionary, as individuals pass through three phases: preliminal, liminal and post-liminal (van Gennep, 1960). Liminality is a state - a process of either being in or passing through a period of uncertainty; a time between two spaces; a void. Thus, liminality can be considered in the context of 'hybridity' as one is a caught in-between shifting binary positions (Neumann, 2012). This echoes the theoretical insights of the location of culture from Homi Bhabha (1994) on hybridity: the 'third-space', 'ambivalence', 'restless' and 'halfway subjects'. In terms of articulation of sporting identities this state of liminal hybridity presents a space where sport fans, as spectators, are able to not feel constrained by the structure of everyday life and take on a new identity. Those in the liminal phase are 'safe' safe in the knowledge that their substantive identity will still be there for them when they return (Aching, 2010; Jaimangal-Jones, Pritchard, \& Morgan, 2010). Victor Turner (1969), further inspects the practice of liminality and famously describes liminality as being 'betwixt and between' places, again spaces of hybridity and transition. In the betwixt and between positions "liminality is created by rituals" (Negrea \& Teodorescu, 2015; Voinea, Negrea, \& Teodorescu, 2015, as cited in Teodorescu and Câlin, 2015, p.98). It is clear in the works of van Gennep (1960) and Turner (1969) that there is a symbolic relationship between liminality and ritual. Today, this continues to be of significance and of functional value to society as Teodorescu and Câlin (2015, p.99) state "the concept of liminality is a product of rituals' process; they cannot have a reaction without each other. Liminality is functioning as a tool in all aspects of the society's rituals." 
Turner (1969) positions liminality within a cultural space that is inherent in laws, customs and ceremonies in society, which are expressed through symbolic rituals significant to people, populations and places in social and cultural contexts. Liminality, in view of rituals, through ceremonies, performances and symbols, is central to establishing, what Turner (1969) refers to as, 'communitas'. It can be argued that sport events echo notions of 'communitas' or camaraderie and sport can be considered as a form of culture and or sub-culture, and a defining characteristic of identity for people, populations and places. As Turner (1969, p.113) states "it has become clear that the collective dimensions, communitas and structure, are to be found in all stages and levels of culture and society." Lee, In, and Seo (2015) observe an interdependency between liminality, communitas, and team identification in a stadium, which encourages repatronage and retention of sport fans to the venue. The feeling of communitas felt among a group in the liminal space through the creation of liminoid moments can have powerful social strategic worth, that extends beyond economic incentives. Chalip $(2006,2014)$ highlights the social value this feeling of communitas has in terms of fostering celebration and camaraderie that can be leveraged effectively from sport events. From a social leverage perspective celebration and camaraderie are essential to creating liminality in sport events as they enable sociability, creation of event-related social events, facilitation of informal social opportunities, production of ancillary events, and theming (Chalip, 2006; O'Brien \& Chalip, 2007). Further, in support of the social leverage of sport events or as a positive social impact, communitas is a tool for promoting social inclusion, addressing social issues, and community relations (O'Brian \& Chalip, 2004; Schulenkorf \& Edwards, 2012; de Haan, Faull, \& Kohe, 2014; Peachey, Lyras, Borland, \& Cohen, 2013; Peachey. Borland, Lobpries, \& Cohen, 2015).

In the liminal space, celebration is a key performative ritualistic element and abstracted from the Latin term Celebro meaning "to honour and to perform as in ritual" (Goldblatt, 2008, p.8). It can thus be suggested, based on Turner's (1982a) statement that "every human society celebrates with ceremony and ritual its joys, sorrows and triumphs" (p.5-6), that celebration is a precondition for people, populations and places. Moreover, celebratory sporting events can be positioned as both public events (Matthews, 2016) and leisure events (Shone and Parry, 2013). Therefore, it can be stated that celebration is integral to the location of the liminal space in sport events because of its symbolic relationship with ritual, communitas, and symbols. Nevertheless, it is clear that the typological reach has extended beyond situating celebration within the boundaries of festivals (Matthews, 2016) and there is an appreciation of the fluidity in the conceptualisations and applications of celebration. However, this is not to suggest that sport cannot be placed in the context of festival for celebration purposes, especially if sport as festival or sport festivals are utilised as a tool for social integration. The Olympic Games, for example, are framed around four areas: spectacle, festival, ritual, game (MacAloon, 1984, as cited in Stevenson \& Alaug, 2000, p.457), as well as football having been expressed in terms of "carnival liminality" (Hognestad, 2003, as cited in St John, 2008, p.164). Sterchele and Saint-Blancat (2015) link sport festivals with the concept of carnivalesque as a non-competitive football tournament is blended with an intercultural festival - the aim to promote a liminal space that is socially inclusive. Festivals and carnivals have long been 
studied and are discussed in relation to liminality (Shields, 1990; Bennett \& Woodward, 2014). With parallels to Bakhtin's (1984) Carnival Mask, these events provide participants the opportunity to hide behind and articulate a new identity. It is the attraction of the liminal moment that allows this, as the new identity needs to be able to undertake behaviours different from the previous one. Sport events, and by extension sport festivals, are therefore ideal examples of liminality at work as people can escape their everyday life for a short-period of time and mask one identity for another.

Within the liminal space we see the suspension of the normal rules that govern behaviour. This leaves a structural vacuum that Turner (1969) calls 'anti-structure'. It is this lack of structure that permits the free abandon of liminal inhabitants, and temporarily removes social status. We see this every week, as on the terraces of the football stadium, clad in the same garb of their tribe, where Doctors stand with street-sweepers all cheering together and willing for the same outcome. Hierarchies may exist, but they have been created within the liminal group by, for example, status given to those with the most knowledge of the team or the most attendance at games (Linden \& Linden, 2017). The inversion of societal norms within the space inevitably means that an environment is created where taboo or normally unacceptable behaviours are practiced and accepted, albeit for a temporary period. This can sometimes manifest as tribal and violent, as with cases of football hooliganism (Giulianotti, 1999). The precise nature of anti-structure is not universally understood. Ravenscroft and Gilchrist (2009) argue that it is not an absence of structure, because the space remains governed and still constrains behaviour. They argue it is, in effect, simply replacing one form of structure with another. Aching (2010) instead suggests it is a more complex social situation that cannot be simplified as inversion or complete absence of social structure. Instead, he describes it as "a social milieu that is thoroughly suffused with competing political and ideological agendas" (p.423).

Closely associated with liminality in the context of ritual is the role of symbols in communitas and celebration in establishing camaraderie among individuals and groups in social and or cultural settings. For Geertz (1973) symbols are synonymous with religion and symbols contribute to the interpretation of cultures - giving recognition to religion as a cultural system. Symbols communicate and transmit beliefs, behaviours, culture, narratives, totems, and/or values that give meaning (e.g. sacred and secular; tangible and intangible) to ritualistic performances, practices and processes. Sport is enriched with symbolic entities (e.g. sport venue / stadium, logos, mascots, flags, anthems, sport ambassadors / celebrities / heroes / icons) which can be linked to aspects of ritualism that are present in the sport event, or what Cheska (1978) refers to as sports spectacular. Symbols, as components of ritual, are mediated in the liminal space in which the fan, as spectator, is immersed in the spectacle. Cheska (ibid) argues:

the cyclical sport event conducted as a large scale impressive public show or display can be called a sport spectacular and a social ritual of power. [...] The sports 
spectacular as a vehicle of symbol contains the basic elements of ritual. According to Klapp (1956, p.13) the elements of ritual are: 1) repetition, 2) regularity, 3) emotionality, 4) drama, 5) symbolism. (p.62)

This link between sport spectacular and symbolism is interpreted further by Stevenson and Alaug (2000) to capture the communitas value of the Olympic Games, for competitors, spectators, and society, by the event organisers:

At their most inclusive, the games are spectacles because they are imbued by the International Olympic Committee with symbolic reality, the notion that [the] nations' participation creates global communitas. [...] Rituals also convey important symbolic messages about the nature of society. (p.457)

\section{Sport Events and the Ritualistic Liminal Space}

Turner (1982b) examined sport in a liminoid context because sport was perceived as a modern and secular individualised performance that departed from van Gennep's (1960) theoretical conceptions of liminality. However, Rowe (2008) argues sport can be viewed as liminal as it is underpinned with ritualistic practices as there is evidence of collective performance, there is a collective spirit, and collective in community. Rowe's (2008) explanations reflect the conceptualisations of celebration (e.g. collective spirit), communitas (e.g. collective community) and symbols (e.g. collective performance) inherent in sport events. Consequently, we continue to inspect sport events as liminal as there is a symbolic and inseparable relationship with rituals, with most sports (e.g. cricket, basketball, football) with an anthropologically rich history. Thus, sport events are embedded with ritualistic behaviours, which are performed by fans, or spectators, pre-event, during event and post-event (McDonald \& Karg, 2014). Moreover, sport and sport events have been likened to a form of religion, given their deep-rooted (e.g. spiritual) connection with solidarity in the ritualistic performativity displayed by fans, as spectators, that is associated with a particular sports culture or team (Cheska, 1978; Serazio, 2013; Fernández Cachán-Cruz, 2014; van Vuuren, 2014). These rituals range from chanting, drinks before and after the sport event, or wearing team kit (McDonald \& Karg, 2014). There is a sense of camaraderie among fans during a sport event, whether this is tangible (e.g. apparel, merchandise, anthems) or intangible (e.g. emotions, myths, nostalgia) as these are symbolic representations of "communal participation or group unity transcending individual existence" (Cheska, 1978, p.64). Lee et al. (2016) emphasise the importance of event spaces (e.g. arenas or stadiums) in developing liminality and forming communitas: "these places encourage casual sociability and strengthen the feeling of belonging and recognition as a member of a social group..." (p.495). The spaces are essential in giving meaning to individuals (Shortt, 2015), but also allows for the symbolic co-construction of meaning (Lucas, 2014).

Lee et al. (2015, p.59) identify a significant contributor to the ritualistic liminal space in sport events - the stadium as a contributor to a "transcendental experience" for the sport 
consumer (i.e. fan and or spectator). The transcendental encounter echoes the theoretical and conceptual perspectives of 'flow' in sport, proposed by Csikszentmihalyi and Csikszentmihalyi (1998), as Lee et al. (2016) state:

Flow theory is based on the idea that people are most happy when they are in a state of concentration or complete absorption with an activity... The flow experience represents an extraordinary experience different from the common pleasures of everyday life... They [participants] may undergo a variety of self-transcending experiences at an event that could lead to a sense of accomplishment or transformation. (p.495)

Although flow experience in the above quote is limited to sport event participants (i.e. athletes) the flow theory can be applied to fans as spectators because, to an extent, they are also participants in the sport venue - making (and re-making) the sportscape. The stadium is core in the transition into the liminal phase, which is not only a place of celebration, communitas, and symbols but also spectacle, drama and festival, infiltrated with a sense of escapism. The stadium where the sport event happens is a 'stage' where sport fans can mask their 'old' identity as they declare their 'new' sport identity, consequently the sport venue is the physical embodiment of the 'betwixt and between'. In the context of ritual, the transcendental space in a stadium can possibly denote a sense and feeling of spirituality as some of the measurable constructs in Lee et al.'s (2015) research, of spectators at a minor league baseball team in Texas, show for liminality: "attending [team] games makes me feel like I am in a new kind of world that differs from outside society" (ibid, p.67), communitas: "when I attend [team] games, I feel a sense of camaraderie" (ibid, p.68), and for team identification: "I consider myself to be a 'real' fan of [the team]" (ibid, p.68).

The creation of the liminal space in sports events is not limited to event organisers as there are several stakeholders involved in designing, implementing and staging the immersive, collective, and transcendental experience. For example, the stadium (including event management and hospitality operations), the athletes / team / club, sponsors, marketers, and sport fans are key players in the establishment of liminality through ritualistic behaviour. McDonald and Karg (2014, p.292) ascertain that "ritual behaviours connected to sporting events and teams are a commonplace example of "co-creation'" in a sporting context. Cocreation suggests that fans as spectators are no longer passive observers but active participators in the liminal sport experience, whether this is before, during and / or after an event. Lee et al. (2016, p.494) note a movement towards "consumer centricity" whereby event participants are co-creating experiences that are personalised and unique to them within the event setting. The co-creation element can be located in Pine and Gilmore's (1999) escapist experience domain ${ }^{1}$ as the emphasis here is upon active engagement and a state of immersiveness is encountered, which is reflective of liminoid liminality. McDonald and Karg (2014) and Lee at al. (2016) recognise this experiential value of co-creation for marketing of the sport event because there is an opportunity to influence fan behaviour in terms of consumption and participation. Lee et al. (2016) propose combining core (e.g. event programme) event products with augmented event experiences (e.g. social programmes). 
The new Tottenham Hotspur stadium (North Tottenham, London, United Kingdom), granted permission in 2016 and to be completed in 2019 (Haringey Council Services, 2016), can be regarded as an embodiment of co-creation in the delivery of core and augmented liminal experiences, such as the public square which will host fan-themed events, pop-up activations that can be explored before the football match and post-match entertainment (e.g. live music) (Tottenham Hotspur, n.d.).

However, liminoid liminality is not limited to the live event experience as fans attending a 'watch party', for example, construct 'intermediate places', which connects 'place, rituals and community' - beyond the sport stadium (Aden et al, 2009). In these 'intermediate places' fans continue to observe (and replicate) rituals central to their sporting culture and identity such as decorating public spaces with team colours or logos, attire, and collective enactments (e.g. shouting, chanting and dancing) (ibid). Also, with the global reach of the social web, sport broadcasting channels and networks can connect spectators anywhere in the world to experience liminality as 'virtual' fans. There is a sense of what Benedict Anderson (1983) referred to as 'imagined communities' because "members of even the smallest nation will never know most of their fellow-members, meet them, or even hear of them..." (ibid, p.6). Although Anderson's (1983) interpretation was based upon nations and nationalism it is still relevant to interpreting communitas in sport as global (imagined) communitas can be established through ritualistic liminal moments that extend beyond physical boundaries ${ }^{2}$. The extent to which the theory of liminality can be applied to 'virtual' fans as spectators of sport events is questionable. As those watching passively from a distance (e.g. at home) on the television or their mobile devices are not physically in the entirety of the liminoid liminal moment with other fans, rather are in a phase of "neo-liminality" (MacAloon, 1984, p.269, as cited in Lewis \& Dowsey-Magog, 1993, p.199). However, with innovation in information communications technology sport organisations are discovering ways of overcoming the neoliminal barrier by engaging virtual fans, across the world, in the match day experience. Manchester United's 'Front Row' initiative with social media platform Google+ used Google+ Hangout technology (a Skype-like, instant messaging and video chat platform) to bring fans from countries around the world together to watch a live Manchester United home game (on 16 March 2014) in the stadium at Old Trafford (Manchester, United Kingdom) on digital screens (Swift, 2014).

\section{Designing Sport Events for Liminal Experiences}

One of the most significant arguments surrounding the relationship between rituals within planned sports events is the extent to which liminality can exist and be created and managed. The interpretations above suggest ritual in sports events is central in designing liminal experiences and creating liminoid happenings in which fans as spectators can make sense of themselves or their environment. Therefore, liminality is, in essence, the most fundamental concept that must be considered before an event can be designed and should also be present before, during and after the sport event - bearing in mind the 'liminal bubble' in which sports fans live. Event design of sport events for liminal experiences should aim to capture celebration, communitas and symbols throughout the liminal cycle. There are different ways 
in which liminality can be designed into an event experience and event organisers need to consider these ways to ensure they are protected within the conceptualisation and conception of event design. In order to design sport events for liminal experiences this chapter draws upon the principles and practices of dramaturgy (Goffman, 1959), atmospherics (Kotler, 1973), and servicescapes (Bitner, 1992), as identified for event design by Ali (2012) and Ali et al. (2017). All three conceptualisations direct event design practice to activate the immersive liminal space in terms of experiences that stimulate emotions, human senses, and interactivity. These three main areas (i.e. drama, atmosphere and the service encounter) will be considered as they can be closely aligned with celebration, communitas, and symbols that are embodied in the ritualistic liminal space. The proposed sport event design strategies to produce liminal experiences builds on the managerial recommendations given by several authors (Cheska, 1978; Chalip, 2006; Lee at al. 2015). Cheska (1978) advances Klapp's (1956) five elements (repetition, regularity, emotionality, drama and symbolism) of ritual by applying them to sports spectacular - of relevance to this chapter is emotionality, drama and symbolism. Lee et al. (2015) encourage event practitioners to create an atmosphere that creates a sense of celebration and celebratory atmosphere through stadium theming to arouse the five senses. In creating liminality associated with celebration and camaraderie for purposes of social leverage, Chalip (2006) suggests for social interaction sport events should aim to: "enable sociability, create event-related social-events, and facilitate informal social opportunities" and for celebration: also "facilitate informal social opportunities, produce ancillary events, and theme widely." $(p, 114)$

Those involved in the design, planning, and management of sport events should aim to create the liminal space by applying the principles and practices of Goffman's (1959) dramaturgy, which, using the metaphor of theatrical performance, identifies that human interaction is dependent on a time, a place, and an audience. These three elements create a stage, framing the expected values, norms and beliefs, guiding the behaviour of individuals who in turn create a front that aligns with their surroundings (Goffman, 1974). In drama or theatrical acts, according to Nelson (2009) the actors are the designers and providers of experiences/services and the audience are the event attendees. However, we would consider sport fans also as actors, bearing in mind the premise of co-creation, because fans are active participants in designing their own / individualised experiences. To design a dramaturgical experience, it is recommended that sport event planners theme sport events in the physical settings (e.g. stadium) and place (e.g. location) where the event is staged. Theming in sport event design has been recognised by several authors as critical to emotionality, escapism and experience (Chalip, 2006, Fernández \& Cachán-Cruz, 2014; Lee et al. 2015), which further boosts feelings of celebration, communitas, and symbolism. The theming of a sport event should not be limited to the arena, stadium or venue where it is being hosted as liminality can be encountered before, during and after an event; subsequently rituals are not confined to specific settings. It may not be possible to theme the entire physical setting and place for a sport event, therefore event planners should work with sport facility managers, destination management organisations, and local businesses, to design specific areas or parts of the event, embedding the theme as widely as possible. With reference to the facets of design 
presented in Sliver's (2007) Event Management Body of Knowledge (EMBOK), sport event practitioners can theme catering, content, entertainment, environment, production, and programme. For example, in addition to sport cafes and bars, food and beverage both in and outside the stadium can be themed to reflect the sport event that is being hosted. As Fernández and Cachán-Cruz (2014) observe in their study of the embodiment of ritualistic practice in sporting environments, menus can be designed innovatively, where dishes were presented under first half, second half, and extra time sections. This intertwines two ritualistic practices, consumption of food and the structure of the sport event, and thus ensures that the event theme can be experienced in every part of the event.

Closely associated with dramaturgy is Kotler's (1973) atmospherics, which determines the atmosphere and ambience of the sport event and plays an important role in creating the celebratory and festive components in the liminal space. Atmospherics, in Kotler's (1973) work, can be closely aligned with the senses of sight, smell, taste, sound, and touch; thus sensory experience can activate emotions through participation in an event. As "ritual makers" (Cheska, 1978) or "ritual specialists" (McDonald \& Kang, 2014, p.299), event designers (and sport fans) need to create (and co-create) liminal spaces, which on the one hand facilitate ritualism and on the other hand activate sensory experiences. Event practitioners need to consider matters of atmospherics beyond the sport facility where the event is being staged, as it appears the atmosphere and ambience or 'feel' for the sport event emerges long before the fans arrive at the stadium. The importance of the journey to and from the event has been shown to enhance the liminal experience (Foster \& McCabe, 2015; Jaimangal-Jones et al, 2010; Luckman, 2014). Also, depending on the result of a competitive sport fixture, fans continue to celebrate / commiserate after the closing of the sport event. McDonald and Karg (2014), inspecting ritualised spectator behaviour, observed fan organised activities; such as organised marches moving toward the venue and post-game congregations in pubs and bars. For event managers there is ample opportunity to capitalise on pre-, during and post-sport event rituals of 'togetherness' and 'inclusivity' by enhancing the existing celebratory and festive atmosphere. In doing so, Chalip (2006) recommends the facilitation of informal social opportunities in order to embrace liminality, which in turn produces communitas. A possible celebratory event that could complement the sport event is a festival, which can be themed around the sport event that will, is or has taken place. There are ample ways in which sports events could be enhanced with festivities, such as the display of club / team / national colours, the use of artefacts or memorabilia associated with the cultural and historical context of the sport event, themed food, sport competitions and games, sport heroes (past and present), meeting and greeting fans, and sport-themed music. Today, sport venues provide ample opportunities to stage event day themed festivals in and around the facility, especially considering new stadium developments (e.g. Tottenham Hotspur Stadium, London, United Kingdom) which will have designated social spaces for attendees and non-attendees. 
Finally, drawing together dramaturgy and atmospherics is Bitner's (1992) servicescapes, which foster emotionality and interactivity, and contributes to the ambience (e.g. music), operational (e.g. venue layout) and symbolic (e.g. brands/sponsors/partners) aspects of the sport event. As the event management industry becomes more professional, so too has the sophistication to which sport venue and event managers approach the development of their craft. While Brown and James (2004) were right to identify that, in the 1990s, there was a primacy to the economics of an event, since then, event managers are increasingly aware that servicescapes are now a requirement of a successful event. The concept of servicescapes draws attention to the relationship between the business (i.e. sport venue and events) and consumer (i.e. sports fan), where there is a negation of the tangible dimensions (e.g. physical environment) and intangible elements (e.g. emotions) associated with consumption. The physical environment in a sport venue can comprise of "layout accessibility, facility aesthetics, seating comfort, electronic equipment, [and] facility cleanliness" (Fernandes \& Neves, 2014, p.5). Emotions can be attached to "reliability, empathy, assurance, responsiveness" (Wakefield \& Blodgett, 1999, as cited in Wakefield \& Blodgett, 2016, p.687). In the sport facility, servicescapes appear to be vast and extensive and can be considered to define the service encounter between the sport fan, the stadium, the sport / sport team or club, and the event. For event planners to provide an emotionally charged and interactive encounter it is proposed that sport venues and event managers create liminal spaces through partner or sponsorship activation initiatives. Penna and Guenzi (2014) observe a "trend in sponsorship ... the growth of activations, that is, the marketing activities a company conducts to promote its sponsorship (also known as leverage)" (p.134). Sponsors and partners use various strategies to communicate their brand to consumers such as product giveaways, competitions, social media/digital initiatives - before, during and after the sport event. In this case liminal spaces can be created for fans that foster transcendental fan experiences at the stadium and destination, and co-created with the sponsor, sport venue and spectator. For example, at the London Rugby Sevens Championships (May 20 - 21, 2017) Samsung presented their 'Samsung Slider' - an innovative seated ride with friction movements, which brought fans closer to the action (Pickup, 2017).

\section{Conclusion}

We began this chapter rejecting the idea that ritual had been lost in modern events. Instead, we have proposed that events, and sport events in particular, are highly ritualised. By using this ritualisation, event managers can create meaningful liminal event experiences. The nature of the liminal space surrounding sport events however adopts a more contemporary liminoid character. It represents a 'fluid' liminality, where participants can enter and exit the liminal space. This requires a new conceptualisation of liminality, considering the entire event experience. In the development of a liminal space, symbols are very important in communicating meaning. They provide a vital tool in developing the legitimacy of the sport event liturgy. This also extends to the physical space, which can allow for co-construction of meaning, as well as signalling new structural norms. While the importance of ritual in historical and religious events was never in doubt, we have demonstrated here that ritual 
plays a vital part in the design of sport events. This builds on the original theories of van Gennep (1909) and Turner (1969) through the application of more up to date concepts that consider the importance of co-creation and the fluidity of the liminal space. There is no reason why this logic could not be broadened further to include a range of other non-secular event types. This holds implications for both management practitioners and event management research.

Our discussion contains a number of implications for managers of sports events. Organisers, being aware that liminal spaces allow for the suspension of the rules that normally govern behaviour, must be prepared to manage unexpected and sometimes unacceptable conduct. They can manage this through first designing spaces that allow for co-creation of meaning, and subsequently signal new structural norms. This has the added benefit of allowing them to take advantage of marketing opportunities, as well as ways to deepen the customer relationship through dramaturgy, immersion, and atmospheric strategies. There is also significant scope to further improve the academic literature, through our understanding of the relationship between liminality and the design of sporting events. We suggest this could be achieved in three ways. First, through more empirical research focused specifically on a sporting event context. This research is likely to be qualitative in nature and seek to understand the complexities of the world in which the sports spectator exists. Second, there is scope for the greater application of social theory to sporting events. Doing so will help to conceptualise phenomena beyond the specific locale of study. There is a particular need to more comprehensively understand the relationship between liminality and structure, especially considering what happens in the absence of structure, and the implications this has for individual agency. This would help understand concepts such as the nature of the identity of the sports event spectator, and the interaction between them and the event. Finally, there is an opportunity for close working between researchers and sport management professionals, to develop practical tools and research that is useful to practitioners. This could take the form of action research, where researchers use these theoretical insights to help practitioners to develop and test different designs or environments to improve the liminal experience. 


\section{References}

Aching, G. (2010). Carnival Time Versus Modern Social Life: A False Distinction. Social Identities, 16(4), pp. 415-425. https://doi.org/10.1080/13504630.2010.497699

Aden, R. C., Borchers, T. A., Buxbaum, A. G., Cross-Mills, K., Davis, S., Dollar, N. J., Mitchell, I. \& Ruggero, A. A. (2009). Communities of Cornhuskers: The Generation of Place through Sports Fans' Rituals. Qualitative Research Reports in Communication, 10(1), pp. 26-37.

Ali, N. (2012). Event Design. In N. Ferdinand and P. Kitchin (eds.) Events Management: An International Approach, pp. 51-69. London: Sage.

Ali, N., Ferdinand, N., and Chidzey, M. (2017). Event Design. In N. Ferdinand and P. Kitchin (Eds.) Events Management: An International Approach, (2 ${ }^{\text {nd }} e d .$, pp. 67-93). London: Sage.

Anderson, B. (1983). Imagined Communities. New York: Verso.

Bakhtin, M. (1984). Rabelais and His World. Bloomington: Indiana University Press

Bennett, A. \& Woodward, I. (2014). Festival Spaces, Identity, Experience and Belonging. In A. Bennett, J. Taylor and I. Woodward (Eds.) The Festivalization of Culture, (pp.11-26) London: Ashgate.

Bhabha, H. K. (1994) The Location of Culture. London: Routledge.

Bitner, M. J. (1992). Servicescapes: The Impact of Physical Surroundings on Customers and Employees. Journal of Marketing, 56(2), pp. 57-71.

Brown, S., and James, J. (2004). Event Design and Management: Ritual Sacrifice? In I. Yeoman, M. Robertson, J. Ali-Knight, S. Drummond and U. McMahon-Beattie (Eds) Festival and Events Management, (pp.53-64). Oxford: Elsevier. 
Chalip, L. (2006). Towards Social Leverage of Sport Events. Journal of Sport and Tourism, 11(2), pp. 109-127. https://doi.org/10.1080/14775080601155126

Chalip, L. (2014). From Legacy to Leverage. In J. Grix (Eds.) Leveraging Legacies from Sports Mega Events: Concepts and Cases, (pp. 2-12). London: Palgrave Macmillan.

Cheska, A. T. (1978). Sports Spectacular: The Social Ritual of Power. Quest. 30(1), pp. 58-71.

Csikszentmihalyi, M., and Csikszentmihalyi, I. S. (1988). Optimal Experience: Psychological Studies of Flow in Consciousness. Cambridge: Cambridge University Press.

Fernandes, T., and Neves, S. (2014). The Role of Servicescape as a Driver of Customer Value in Experience-Centric Organisations: The Dragon Football Stadium Case. Journal of Strategic Marketing, 22(6), pp.548-560. https://doi.org/10.1080/0965254X.2014.914058

Fernández, O., and Cachán-Cruz, R. (2014). An Assessment of the Dynamic of Religious Ritualism in Sporting Environments. Journal of Religion and Health, 53, pp. 1653-1661.

Finkel, R. (2010). Re-imaging Arts Festivals through a Corporate Lens: A Case Study of Business Sponsorship at the Henley Festival. Managing Leisure, 15(4), pp. 237-250. https://doi.org/10.1080/13606719.2010.508664

Foster, C., \& McCabe, S. (2015). The role of liminality in residential activity camps. Tourist Studies, 15(1), pp.46-64. https://doi.org/10.1177/1468797614550962

Geertz, C. (1973). The Interpretation of Cultures. New York: Basic Books.

van Gennep, A. (1960). The Rites of Passage. Chicago: University of Chicago Press.

Goffman, E. (1959). The Presentation of Self in Everyday Life. New York: Anchor Books.

Goffman, E. (1974). Frame Analysis: An essay on the organization of experience. Cambridge, MA: Harvard University Press. 
Goldblatt, J.J. (2008). Special Events: The Roots and Wings of Celebration (5th Ed.). Hoboken NJ: John Wiley \& Sons.

Goldblatt, J. J. (2011). Special Events: A New Generation and the Next Frontier (6 th $^{\text {Ed.). }}$ Hoboken NJ: John Wiley \& Sons.

Giulianotti, R. (1999). Football: A Sociology of the Global Game. Cambridge: Polity Press

de Haan, D., Faull, A. \& Kohe, G. Z. (2014). Celebrating the Social in Soccer: Spectators' Experiences of the Forgotten (Blind) Football World Cup. Soccer \& Society, 15(4), pp. 578-595.

Haringey Council Services. (2016). Tottenham Hotspur Football Club Stadium Development (online). Retrieved from: https://www.haringey.gov.uk/planning-and-buildingcontrol/planning/major-projects-and-regeneration/tottenham-hotspur-football-clubstadium-development (Accessed: $28^{\text {th }}$ September 2018)

Jaimangal-Jones, D., Pritchard, A. \& Morgan, N. (2010). Going the Distance: Locating Journey, Liminality and Rites of Passage in Dance Music Experiences. Leisure Studies, 29(3), pp. 253268. https:/doi.org/10.1080/02614361003749793

Kotler, P. (1973). Atmospherics as a Marketing Tool. Journal of Retailing, 4, pp. 48-64.

Lawson, F. R. S. (2011). Music in Ritual and Ritual in Music: A Virtual Viewer's Perceptions about Liminality, Functionality, and Mediatiztion in the Opening Ceremony of the 2008 Beijing Olympic Games. Asian Music, 42(2), pp. 3-18.

Lee, S., In, S. \& Seo, W. J. (2015). Repeat Attendance as a Function of Liminality, Communitas and Team Identification. South African Journal for Research in Sport, Physical Education and Recreation. 37(1), pp. 59-76.

Lee, I. S., Brown, G., King, K. \& Shipway, R. (2016). Social Identity in Serious Event Space. Event Management, 20(4), pp. 491-499. https:/doi.org/10.3727/152599516X14745497664352 
Lewis, J. \& Dowsey-Magog, P. (1993). The Maleny 'Fire Event': Rehearsals Toward NeoLiminality. The Australian Journal of Anthropology, 4(3), pp. 198-219.

Linden, H., \& Linden, S. (2017). Fans and Fan Cultures, London: Palgrave MacMillan.

Lucas, M. (2014). 'Nomadic' organization and the experience of journeying: Through liminal spaces and organizing places. Culture and Organization, 20(3), pp.196-214. https://doi.org/10.1080/14759551.2014.897346

Luckman, S. (2014). Location, Spatiality and Liminality at Outdoor Music Festivals: Doofs as Journey. In A. Bennett, J. Taylor and I. Woodward (Eds.) The Festivalization of Culture, (pp.189206) London: Ashgate.

Matthews, D. (2014). Special Event Production: The Process (2 ${ }^{\text {nd }}$ Ed.). Oxon: Routledge.

Maussier, B. (2017). The New Ethical Dimensions of Sport Events: a Reflection of the Evolution from the Ancient Greek Olympic Sports Festival to Postmodern Sport Events. Cultura, Ciencia y Deporte, 12(34), pp. 15-25.

McDonald, H., \& Karg, A. J. (2014). Managing Co-creation in Professional Sports: The Antecedents and Consequences of Ritualized Spectator Behaviour. Sport Management Review, 17, pp. 292-309.

Nelson, K. B. (2009). Enhancing the Attendee's Experience through Creative Design of the Event Environment: Applying Goffman's Dramaturgical Perspective. Journal of Convention and Event Tourism, 10, pp. 120-133.

Neumann, I. B. (2012). Introduction to the Forum on Liminality. Review of International Studies, 38, pp. 473-479.

O' Brien, D. \& Chalip, L. (2004). Sport Events and Strategic Leveraging: Pushing Towards the Triple Bottom Line. In A. G. Woodside and D. Martin (eds.) Tourism Management, (pp. 318338). Oxford: $C A B I$ International. 
Peachey, J. W., Lyras, A., Borland, J., \& Cohen, A. (2013). Street Soccer USA Cup: Preliminary Findings of a Sport-for-Homeless Intervention. ICHPER-SD Journal of Research, 8(1), pp3-11.

Peachey, J. W., Borland, J., Lobpries, J., \& Cohen, A. (2015). Managing Impact: Leveraging Sacred Spaces and Community Celebration to Maximize Social Capital at a Sport-forDevelopment Event. Sport Management Review, 18, pp. 86-98.

Penna, D., \& Guenzi, P. (2014). How to Use a Sponsorship Platform to Support an International Master Brand Strategy: The UniCredit UEFA Champions League Sponsorship. Journal of Brand Management, 21(2), pp. 133-149.

Pickup, O. (2017, May 9) The Samsung Slider: The Ultimate Viewing Experience. The Telegraph (Online). Retrieved from: https://www.telegraph.co.uk/ (Accessed: $1^{\text {st }}$ August 2018).

Pine, J. B., \& Gilmore, J. H. (1999). The Experience Economy. Massachusetts: Harvard Business Press.

Rowe, S. (2008). Modern Sports: Liminal Ritual or Liminoid Leisure? In G. St John (Ed.). Victor Turner and Contemporary Cultural Performance, (pp. 127-148). New York and Oxford: Berghahn Books.

Schulenkorf, N., \& Edwards, D. (2012). Maximising Positive Social Impacts: Strategies for Sustaining and Leveraging the Benefits of Intercommunity Sport Events in Divided Societies. Journal of Sport Management, 26, pp. 379-390.

Serazio, M. (2013). The Elementary Forms of Sports Fandom: A Durkheimian Exploration of Team Myths, Kinship and Totemic Rituals. Communication Faculty Publications. Paper 40. (Online) Available at: http://digitalcommons.fairfield.edu/communications-facultypubs/40 (Accessed: $15^{\text {th }}$ March 2018).

Shields, R. (1990). The 'System of Pleasure': Liminality and the Carnivalesque at Brighton. Theory, Culture and Society, 7, pp. 39-72.

Shone A. \& Parry, S. (2013). Successful Event Management: A Practical Handbook. Hampshire: Cengage. 
Shortt, H. (2015). "Liminality, space and the importance of 'transitory dwelling places' at work", Human Relations, 68(4), pp. 633-658. https://doi.org/10.1177/0018726714536938

Silvers, J. (2007). EMBOK Facets and Applications. (Online) Available at: http://www.juliasilvers.com/embok/Facets_Aps.htm (Accessed: $1^{\text {st }}$ August 2018).

St John, G. (2008). Trance Tribes and Dance Vibes: Victor Turner and Electronic Dance Music Culture. In G. St John (ed.) Victor Turner and Contemporary Cultural Performance, (pp. 149173). New York and Oxford: Berghahn Books.

Sterchele, D., \& Saint-Blancat, C. (2015). Keeping it Liminal. The Mondiali Antirazzisti (Antiracist World Cup) as a Multifocal Interaction Ritual. Leisure Studies, 34(2), pp. 182-196.

Stevenson, T. B., \& Alaug, A. K. (2000). Football in Newly United Yemen: Rituals of Equity, Identity, and State Formation. Journal of Anthropological Research, 56(4), pp. 453-475.

Swift, J. (2014) Man Utd Teams with Google+ for Pitch-Side Digital Competition. (Online) Campaign. Available at: https://www.campaignlive.co.uk/article/man-utd-teams-googlepitch-side-digital-competition/1282798 (Accessed: $30^{\text {th }}$ July 2018).

Teodorescu, B., \& Câlin, R. A. (2015). The Base Articulations of the Liminality Concept. Review of European Studies, 7(12), pp. 97-102. https://doi.org/10.5539/res.v7n12p97

Thomassen, B. (2009). The Uses and Meanings of Liminality. International Political Anthropology, 2, pp. 5-27.

Tottenham Hotspur (n.d). Be There. Available at: http://newstadium.tottenhamhotspur.com/be-there (Accessed: $30^{\text {th }}$ July 2018).

Turner, V. (1969). The Ritual Process: Structure and Anti-Structure. Chicago: Aldine. 
Turner, V. (1982a). Celebration, Studies in Festivity and Culture. Michigan: University of Michigan.

Turner, V. (1982b). From Ritual to Theatre: The human seriousness of play. New York: PAJ Publications.

van Vuuren, C. J. (2014). A Ritual Perspective on the Comrades Marathon. South African Journal of Research in Sport, Physical Education and Recreation, 36(2), pp. 211-224.

Wakefield, K. L., \& Blodgett, J. (2016). Retrospective: The Importance of Servicescapes in Leisure Service Setting. Journal of Services Marketing, 30(7), pp. 686-691.

${ }^{1}$ Pine and Gilmore (1999) examined four domains of experience: educational, entertainment, esthetic, and escapist that transcend from passive to active, and absorption to immersion. These domains are: Educational: active participation and absorption in the setting; Entertainment: passive participation and absorption of the attendee; Esthetic: passive participation and immersion; and, Escapist: active participation and immersion.

2 See Aden et al, (2009) for similarities between imagined community and intermediate places. 